\title{
ANALIZA WYBRANYCH UWARUNKOWAŃ ORGANIZACYJNO-EKONOMICZNYCH W PAŃSTWOWYM GOSPODARSTWIE LEŚNYM LASY PAŃSTWOWE
}

\section{Abstract \\ Analysis of selected organizational and economic conditions in State Forests National Forest Holding}

This paper presents the findings of a research study targeted at verification whether the disbursement of funds at the disposal of the State Forests National Forest Holding (hereinafter: the State Forests) corresponded to the tasks in the field of forest management imposed on the institution in question under the provisions of applicable law and whether it was justifiable in the context of the principle of rational management of public funds. The research was based on the analysis of the secondary data collected by the Directorate General of the State Forests, official statistical data, post-audit information of the Supreme Audit Office and literature covering the research area. The results of research carried out on the basis of data from 2011-2016 showed that the general property and financial situation of the State Forests in the analysed period was favourable due to the fact that each year the aforementioned institution recorded a significant net profit. The activities implemented by the State Forests were in principle compatible with a model of sustainable forest management specified in the Forest Act, however in case of incurring investment outlays of fixed assets not directly related to forest management, the principle of rational management of public funds was not always fully applied. Therefore, the conscious economic calculation should constitute the basis for conducting investment activities by the State Forests.

Keywords: state forests, organizational and economic conditions, forest management

\section{Streszczenie}

W artykule przedstawiono wyniki badań mających na celu sprawdzenie, czy wydatkowanie środków będących w dyspozycji Państwowego Gospodarstwa Leśnego Lasy Państwowe (dalej: Lasy Państwowe) odpowiadało zadaniom w zakresie gospodarki leśnej nałożonym na tę instytucję na podstawie przepisów obowiązującego prawa i czy było ono uzasadnione w kontekście 
zasady racjonalnego gospodarowania środkami publicznymi. Badania oparto na analizie danych wtórnych zebranych przez Dyrekcję Generalną Lasów Państwowych, oficjalnych danych statystycznych, informacji pokontrolnej Najwyższej Izby Kontroli oraz literaturze obejmującej obszar badań. Wyniki badań przeprowadzonych na podstawie danych z lat 2011-2016 wykazały, że ogólna sytuacja majątkowa i finansowa Lasów Państwowych w analizowanym okresie była korzystna ze względu na fakt, że co roku wspomniana instytucja odnotowywała znaczący zysk netto. Działania realizowane przez Lasy Państwowe były zasadniczo zgodne z modelem zrównoważonej gospodarki leśnej określonym w ustawie o lasach, jednak w przypadku ponoszenia nakładów inwestycyjnych na środki trwałe niezwiązane bezpośrednio z gospodarką leśną, zasada racjonalnego zarządzania środkami publicznymi nie zawsze miała pełne zastosowanie. Stąd też rachunek ekonomiczny powinien stanowić podstawę do prowadzenia działalności inwestycyjnej przez Lasy Państwowe.

Słowa kluczowe: lasy państwowe, uwarunkowania organizacyjno-ekonomiczne, gospodarka leśna

\section{Wprowadzenie}

Lasy - bez względu na formę własności - mają niezwykle istotne znaczenie zarówno przyrodnicze, jak i społeczno-gospodarcze. Państwowe Gospodarstwo Leśne Lasy Państwowe (dalej: LP) jest nieposiadającą osobowości prawnej państwową jednostką organizacyjną, która zarządza lasami stanowiącymi własność Skarbu Państwa [Tyburek, 2010: 118; Szramka, Adamowicz, 2017: 355]. Lasy będące w zarządzie LP zajmują powierzchnię 7105 tys. ha, co stanowi 77\% powierzchni lasów w Polsce [GUS, 2017: 37]. Zgodnie ze Sprawozdaniem finansowo-gospodarczym za 2016 rok jednostki organizacyjne LP wygenerowały przychody równe prawie 8,41 mld zł, z czego kwota 404,03 mln zł stanowiła zysk netto, przy czym główne źródło przychodów stanowiła sprzedaż surowca drzewnego [DGLP, 2017: 13]. W konsekwencji, prowadząc działalność na zasadzie samodzielności finansowej [Maćkowiak, 2016: 114], LP są największym w Unii Europejskiej podmiotem zarządzającym lasami publicznymi [Bieluk, Leśkiewicz, 2017]. W ramach tego zarządu, poza prowadzeniem ewidencji majątku Skarbu Państwa i ustalaniem jego wartości [Szczypa, 2016: 176], LP prowadzą gospodarkę leśną, gospodarkę gruntami i innymi nieruchomościami oraz ruchomościami związanymi z gospodarką leśną, takimi jak: tartaki i składnice drewna, gospodarstwa rybackie czy baza szkoleniowo-wypoczynkowa. Oprócz działalności gospodarczej LP realizują również zadania z zakresu ochrony zasobów leśnych, co implikuje swego rodzaju dualizm prawnoorganizacyjny tej instytucji [NIK, 2015: 6].

Podstawowym aktem prawnym regulującym działalność LP, w tym w szczególności strukturę organizacyjną oraz sposób prowadzenia gospodarki finansowej, jest ustawa z dnia 28 września 1991 roku o lasach (Dz.U. 2017, poz. 788 tekst jedn. ze zm.). Zgodnie z jej przepisami LP kieruje Dyrektor Generalny LP za pomoca dyrektorów właściwych regionalnych dyrekcji LP. Z kolei w skład regionalnych dyrekcji wchodzą nadleśnictwa - podstawowe jednostki organizacyjne LP. Koszty utrzymania Dyrekcji Generalnej LP oraz dyrekcji regionalnych LP pokrywane są 
z wpłat obciążających koszty działalności nadleśnictw [Radecki, 2017: 453]. Nadleśniczy samodzielnie prowadzą gospodarkę leśną w nadleśnictwach na podstawie planów urządzenia lasu oraz odpowiadają za stan lasów. Nadzór nad LP sprawuje Minister Środowiska, jednakże zarówno samo pojęcie nadzoru, jak i środki kontroli nadzorowanej działalności nie zostały w ustawie precyzyjnie zdefiniowane, co powoduje, że zakres dyskrecjonalnych kompetencji Dyrektora Generalnego LP jest relatywnie szeroki [Habuda, Radecki, 2016: 264]. W związku z tym, przy tak dużej skali i swobodzie działania LP, prowadzenie gospodarki finansowej przez tę instytucję w zgodzie $\mathrm{z}$ zasadą racjonalnego gospodarowania środkami publicznymi, to jest ich rozdysponowanie w sposób celowy i oszczędny, dążąc przy tym do uzyskiwania najlepszych efektów z danych nakładów, stanowi zagadnienie o doniosłym znaczeniu [Szołno-Koguc, 2007: 63].

\section{Materiały i metody}

Mając na uwadze ważność wskazanego problemu oraz długookresowy charakter działalności LP, sprowadzający się do działań nie tylko stricte ekonomicznych, lecz także przyrodniczych, społecznych i kulturowych [Sadowska, 2016: 401], celem niniejszego artykułu była próba analizy i oceny funkcjonowania LP na przykładzie wybranych aspektów organizacyjno-ekonomicznych w zakresie działalności podstawowej oraz działalności administracyjnej LP. Przede wszystkim podjęto próbę udzielenia odpowiedzi na następujące pytanie badawcze: czy wydatkowanie środków finansowych będących w dyspozycji LP odpowiadało zadaniom z zakresu gospodarki leśnej nałożonym na przedmiotową instytucję na mocy przepisów powszechnie obowiązującego prawa i czy znajdowało to swoje uzasadnienie w kontekście zasady racjonalnego gospodarowania środkami publicznymi?

W artykule zastosowano w głównej mierze następujące metody: analizę źródłową, analizę logiczną i analizę porównawczą. Podstawę badań teoretycznych stanowiły obowiązujące regulacje normatywne oraz literatura z zakresu obszaru badawczego, a badania empiryczne w zakresie gospodarki finansowej LP zostały dokonane na podstawie danych wtórnych pochodzących z Dyrekcji Generalnej LP w formie rocznych sprawozdań finansowo-gospodarczych, informacji pokontrolnych Najwyższej Izby Kontroli oraz oficjalnych danych statystycznych. W celu uzyskania miarodajnych wyników przeprowadzonych analiz badaniem objęto lata 2011-2016.

\section{Wyniki}

Zgodnie z przepisami ustawy o lasach zasadniczym celem LP jest prowadzenie gospodarki leśnej według zasad powszechnej ochrony lasów, trwałości ich utrzymania, ciągłości i zrównoważonego wykorzystania wszystkich funkcji 
lasów oraz powiększania zasobów i upraw leśnych. Przedmiotowy cel LP realizują przez prowadzenie trwale zrównoważonej gospodarki leśnej polegającej w szczególności na kształtowaniu struktury lasów i ich wykorzystaniu w sposób zapewniający trwałe zachowanie ich walorów biologicznych, wysokiej produkcyjności oraz potencjału regeneracyjnego. LP prowadzą działalność na zasadzie samodzielności finansowej i pokrywają koszty działalności z własnych przychodów [Kropiewnicka, Ostrowiecki, 2014: 224; Maćkowiak, 2016: 114]. W związku z tym w celu optymalizacji wykorzystania publicznych środków finansowych działalność gospodarcza LP, włączając w to działalność inwestycyjną, powinna być prowadzona na podstawie rachunku ekonomicznego [NIK, 2015: 23].

Jak wskazano na wstępie, głównym źródłem przychodów LP jest sprzedaż drewna. W badanym okresie najniższe przychody ze sprzedaży tego surowca osiągnięto w roku 2013 (6 297 759,3 tys. zł), a najwyższe w roku 2016 (7 432 090,5 tys. zł), co stanowiło odpowiednio 86,9\% i 88,6\% przychodów LP ogółem (zob. wykres 1). Pozostałe źródła przychodów, takie jak na przykład gospodarka łowiecka czy sprzedaż materiałów i przychody z pozostałej sprzedaży, miały istotnie mniejsze znaczenie.

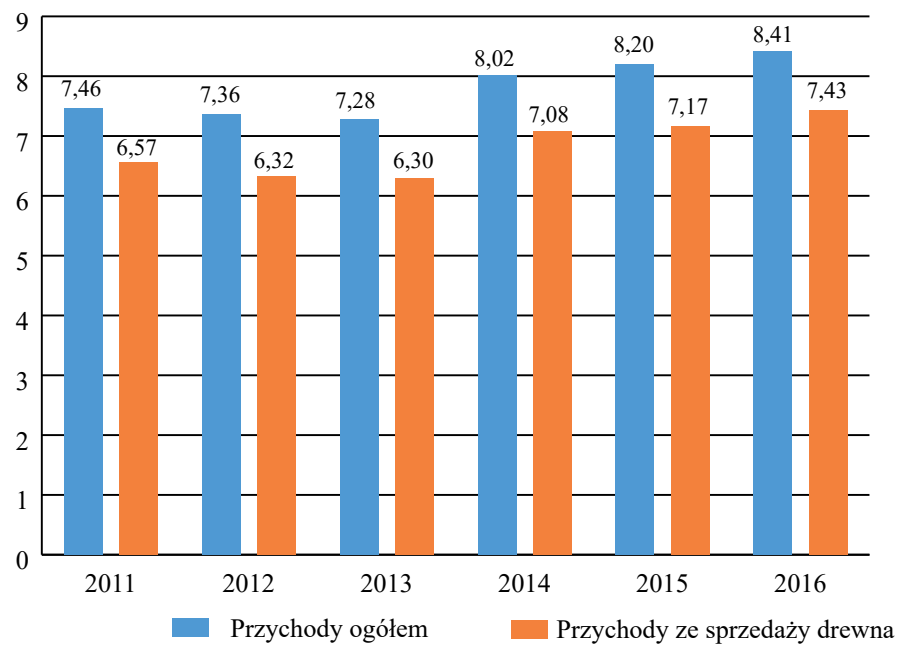

Wykres 1 . Zmiany wysokości przychodów ogółem oraz przychodów ze sprzedaży drewna w LP w latach 2011-2016 (w mld zl)

Źródło: opracowanie własne na podstawie sprawozdań finansowo-gospodarczych LP za lata 2011-2016.

Jak można zaobserwować na wykresie 1, w latach 2011-2013 przychody LP ze sprzedaży surowca drzewnego zmniejszyły się odpowiednio z 6566 962,2 tys. zł do 6297 759,3 tys. zł. Wyraźny wzrost przychodów w tym zakresie można było natomiast zaobserwować w latach 2014-2016 - LP uzyskały przychody ze sprzedaży 
drewna w kwocie 7081 869,3 tys. zł w 2014 roku, a w 2016 r. kwota z tego tytułu wyniosła 7432 090,5 tys. zł. Powyższe zmiany wysokości przychodów w badanym okresie występowały pomimo prowadzenia przez LP polityki stopniowego zwiększania podaży drewna - z 35,08 $\mathrm{mln} \mathrm{m}^{3} \mathrm{w} 2011$ roku do 39,45 $\mathrm{mln} \mathrm{m}^{3}$ w 2016 roku [GUS, 2017: 326]. Obserwowane różnice w przychodach były zapewne skorelowane ze zmianami przeciętnej ceny drewna w danym roku - a zatem czynnika nie do końca zależnego od LP. Tytułem przykładu można wskazać, że w 2011 roku przeciętna cena drewna za $1 \mathrm{~m}^{3}$ kształtowała się na poziomie 188,27 zł, a w 2016 roku była niewiele wyższa, gdyż wynosiła 188,92 zł [GUS, 2017: 111]. Co ważne, zgodnie $z$ danymi zawartymi w sprawozdaniach finansowogospodarczych LP za lata 2011-2016 w analizowanym okresie podmiot ten corocznie odnotowywał znaczny zysk netto, który wynosił: 829,14 mln zł w 2011 roku, 259,60 mln zł w 2012 roku, 304,97 mln zł w 2013 roku, 421,70 mln zł w 2014 roku, 382,16 mln zł w 2015 roku oraz 404,03 mln zł w 2016 roku.

W świetle zasady racjonalnego gospodarowania środkami publicznymi należy stwierdzić, że wydatkowanie tak znacznych środków publicznych przez LP, w tym prowadzenie działalności inwestycyjnej, powinno być ściśle związane ze wzmocnieniem podstawowego źródła przychodów oraz zmierzać do osiągnięcia optymalnych efektów przy kosztach określonych na racjonalnym poziomie. W badanym okresie poddano więc analizie koszty działalności podstawowej LP (to jest przede wszystkim hodowli i ochrony lasu oraz pozyskania i zrywki drewna) do kosztów działalności administracyjnej, obejmującej głównie utrzymanie Służby Leśnej, a także pozostałą działalność administracyjną nadleśnictw [DGLP, 2017: 9], co prezentuje wykres 2 . Warto przy tym nadmienić, że obie kategorie kosztów każdorocznie łącznie stanowiły zdecydowanie największą część kosztów ogółem LP.

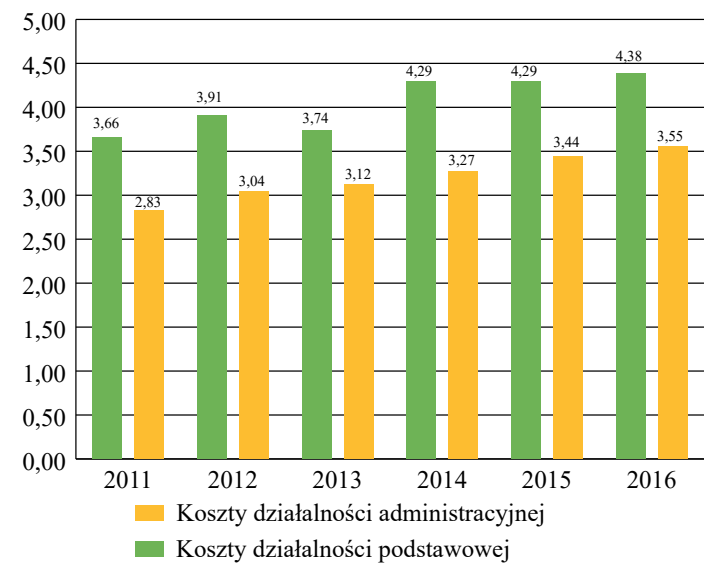

Wykres 2. Zmiany wysokości kosztów działalności podstawowej i kosztów działalności administracyjnej LP w latach 2011-2016 (w mld zl)

Źródło: opracowanie własne na podstawie sprawozdań finansowo-gospodarczych LP za lata 2011-2016. 
Jak można zatem zaobserwować na wykresie 2, pomimo pewnych zmian dynamiki wzrostu kosztów działalności podstawowej LP w latach 2011-2016 nastąpił dynamiczny i stabilny wzrost kosztów działalności administracyjnej. W całym badanym okresie koszty działalności administracyjnej LP były relatywnie wysokie. Tytułem przykładu można wskazać, że w 2013 roku wyniosły one $3119,55 \mathrm{mln}$ zł, a koszty działalności podstawowej LP wyniosły $3742,97 \mathrm{mln}$ zł, a więc były to kwoty porównywalne. W tym kontekście warto zwrócić uwagę na fakt, że analiza stanu zatrudnienia w LP w latach 2011-2016 wykazała wyraźne zwiększenie zatrudnienia ogółem w tej instytucji. W 2016 roku zatrudnienie ogółem w LP wyniosło 25747 osób i w stosunku do 2011 roku było ono wyższe o 949 osób, przy czym pracownicy Służby Leśnej stanowili zdecydowanie największą grupę zatrudnionych [GUS, 2017: 327]. Równolegle w tym samym okresie nastąpił dynamiczny wzrost wynagrodzeń w LP, które były prawie dwukrotnie wyższe od wynagrodzeń w gospodarce narodowej. Wykres 3 prezentuje zmiany wysokości przeciętnego wynagrodzenia miesięcznego ogółem w LP w poszczególnych latach analizowanego okresu na tle analogicznej kategorii danych odnoszących się do gospodarki narodowej.

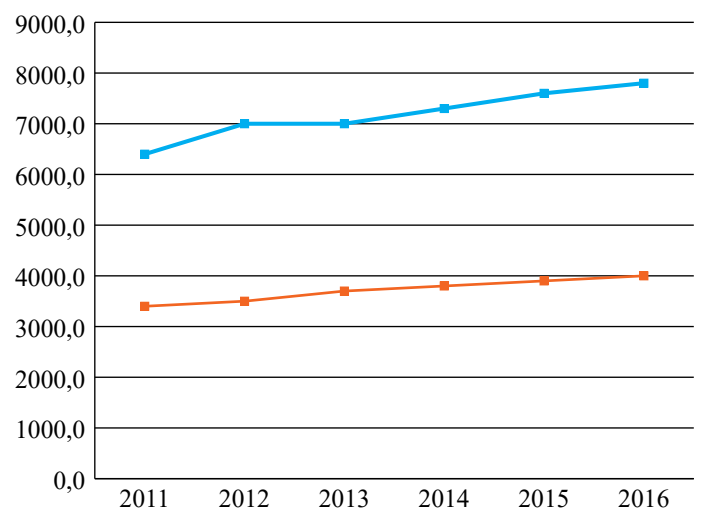

\begin{tabular}{|l|c|c|c|c|c|c|}
\cline { 2 - 7 } \multicolumn{1}{c|}{} & 2011 & 2012 & 2013 & 2014 & 2015 & 2016 \\
\hline — LP & 6389,9 & 6987,3 & 6979,5 & 7229,0 & 7548,9 & 7772,0 \\
\hline Gospodarka narodowa & 3399,5 & 3521,7 & 3650,1 & 3783,5 & 3899,8 & 4047,2 \\
\hline
\end{tabular}

Wykres 3. Zmiany wysokości przeciętnego wynagrodzenia miesięcznego ogółem w LP oraz w gospodarce narodowej w latach 2011-2016 (w zl)

Źródło: opracowanie własne na podstawie: www.stat.gov.pl (dostęp: 26.07.2018).

Jeśli chodzi o działalność inwestycyjną LP, to w latach 2011-2013 nakłady na budowę środków trwałych wzrosły z 943,6 mln zł do 1123,0 mln zł. Z kolei w latach 2014-2016 można było zaobserwować znaczący spadek tych nakładów do kwoty 573,6 mln zł [GUS, 2017: 328]. Równocześnie warto zauważyć, iż z analizy 
wysokości ponoszonych rokrocznie przez LP kosztów ochrony i hodowli lasu, które są kluczowe dla właściwego prowadzenia trwale zrównoważonej gospodarki leśnej, wynika, że począwszy od roku 2011 (849,9 mln zł) wykazywały one wyraźne tendencje wzrostowe, by w roku 2015 osiągnąć wartość 1022,7 mln zł (zob. wykres 4).

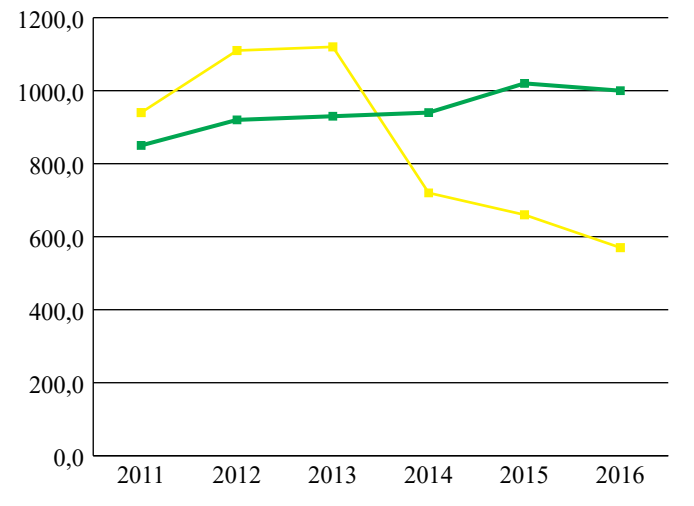

\begin{tabular}{|c|c|c|c|c|c|c|c|}
\hline & & 2011 & 2012 & 2013 & 2014 & 2015 & 2016 \\
\hline 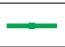 & $\begin{array}{l}\text { Koszt hodowli } \\
\text { i ochrony lasu }\end{array}$ & 849,9 & 916,2 & 933,7 & 935,0 & 1022,7 & 1002,7 \\
\hline$=$ & $\begin{array}{l}\text { Nakłady na budowe } \\
\text { środków trwałych }\end{array}$ & 943,6 & 1113,4 & 1123,0 & 718,9 & 660,1 & 573,6 \\
\hline
\end{tabular}

Wykres 4. Zmiany wysokości kosztów hodowli i ochrony lasu oraz nakładów na budowę środków trwałych w LP w latach 2011-2016 (w mln zf)

Źródło: opracowanie własne na podstawie: www.stat.gov.pl (dostęp: 26.07.2018).

Przedstawiony na wykresie 4 pozytywny trend w zakresie zwiększenia wydatków poniesionych na hodowlę i ochronę lasu przy jednoczesnej znaczącej redukcji nakładów na budowę środków trwałych w LP jest dalece zbieżny z uwagami i wnioskami Najwyższej Izby Kontroli wyartykułowanymi w tym przedmiocie W wystąpieniach pokontrolnych skierowanych do osób kierujących jednostkami organizacyjnymi LP, które w latach 2014-2015 zostały poddane kontroli stanu majątkowo-finansowego oraz efektywności prowadzonej działalności gospodarczej. W trakcie wykonywania czynności kontrolnych stwierdzone zostały przypadki ponoszenia przez LP wysokich wydatków na przedsięwzięcia inwestycyjne niemające ścisłego związku z realizacją zadań wynikających z przepisów obowiązującego prawa. O ile celowość ponoszenia przez LP wydatków inwestycyjnych na poprawę jakości dróg w lasach nie budziła zastrzeżeń NIK, o tyle zakwestionowane zostały niepoparte analizami ekonomicznymi wysokie nakłady na zakup, modernizację i remonty niektórych budynków administracyjno-biurowych, ośrodków szkoleniowo-wypoczynkowych, kwater myśliwskich oraz budynków mieszkalnych, w których standard wykonywanych prac był niejednokrotnie bardzo wysoki. Jako przykłady takich działań wskazano zakup nieruchomości 
z przeznaczeniem na nową siedzibę Dyrekcji Generalnej LP w Warszawie (nabycie prawa użytkowania wieczystego trzech działek gruntów oraz prawa własności trzech budynków za kwotę ponad 62,4 mln zł) czy rozbudowę Ośrodka Wypoczynkowego „Leśnik” w Łagowie (prace budowlane obejmowały dobudowę sali konferencyjnej z zapleczem oraz pokojami hotelowymi o łącznej powierzchni użytkowej $473 \mathrm{~m}^{2}$ za kwotę ponad $3 \mathrm{mln}$ zł) [NIK, 2015: 24-27].

\section{Podsumowanie}

Wyniki badań przeprowadzonych na podstawie danych z lat 2011-2016 wykazały, że ogólna sytuacja finansowo-majątkowa LP w analizowanym okresie była korzystna. Corocznie instytucja ta odnotowywała istotny zysk netto, choć w niektórych latach wysokości kwot wypracowanego zysku różniły się w sposób znaczący (na przykład w 2011 roku zysk netto wyniósł 829,14 mln zł, a w 2012 roku $259,60 \mathrm{mln}$ zł). Dysproporcje w tym zakresie były zapewne w dużej mierze spowodowane zmianami średniej ceny surowca drzewnego $\mathrm{w}$ danym roku, co jedynie do pewnego stopnia było zależne od polityki sukcesywnego zwiększania podaży drewna prowadzonej przez LP. Ponadto mimo pozytywnych zmian zapoczątkowanych w 2014 roku środki finansowe przeznaczane przez LP na hodowlę i ochronę lasu, czyli nakłady o zasadniczym znaczeniu dla utrzymania i powiększania zasobów i ekosystemów leśnych, w 2016 roku były nadal dużo niższe od kosztów działalności administracyjnej. Z kolei wzrost wynagrodzeń w LP, które i tak zostały określone na dość wysokim poziomie (w latach 20112016 przeciętne wynagrodzenie miesięczne w LP prawie dwukrotnie przewyższało wysokość analogicznej kategorii wynagrodzeń w gospodarce narodowej), następowały w oderwaniu od zróżnicowania osiąganych wyników finansowych przez ten podmiot.

W badanym okresie analizowane działania realizowane przez LP zasadniczo wpisywały się w model prowadzenia trwale zrównoważonej gospodarki leśnej określony w ustawie o lasach, jednakże pewne wątpliwości co do zgodności z podstawowymi celami funkcjonowania LP mogły budzić niektóre przejawy działalności inwestycyjnej bezpośrednio niezwiązane z gospodarką leśną. Wyniki kontroli NIK wykazały, że w niektórych obszarach, zwłaszcza tych skorelowanych z ponoszeniem nakładów na budowę środków trwałych, zasada racjonalnego gospodarowania środkami publicznymi nie zawsze miała pełne zastosowanie. W celu praktycznej implementacji tej zasady podstawą prowadzenia działalności inwestycyjnej LP powinien być rachunek ekonomiczny, a podejmowanie wszelkich przedsięwzięć inwestycyjnych powinno być poprzedzone dokonaniem odpowiednich analiz ekonomicznych, zwłaszcza że głównym zadaniem tej instytucji jest prowadzenie trwale zrównoważonej gospodarki leśnej w lasach stanowiących własność Skarbu Państwa. 


\section{Bibliografia}

Bieluk J., Leśkiewicz K. (2017), Ustawa o lasach. Komentarz, Legalis.

Habuda A., Radecki W. (2016), Zarządzanie lasami [w:] A. Habuda (red.), Polskie prawo leśne, Difin, Warszawa.

Kropiewnicka M., Ostrowiecki D. (2014), Zmiany w Lasach Państwowych. Analiza modelu gospodarki leśnej w Polsce [w:] B. Rakoczy, M. Szalewska, K. Karpus (red.), Prawne aspekty gospodarowania zasobami środowiska. Korzystanie z zasobów środowiska, Towarzystwo Naukowe Organizacji i Kierownictwa, Toruń.

Maćkowiak E. (2016), Finansowe podstawy działalności Państwowych Gospodarstw Leśnych Lasy Państwowe, „Problemy Zarządzania”, 14/4 (1).

Radecki W. (2017), Ustawa o lasach. Komentarz, Wolters Kluwer Polska, Warszawa.

Sadowska B. (2016), System pomiaru dokonań w Państwowym Gospodarstwie Leśnym Lasy Państwowe - proces przygotowania i implementacji [w:] R. Kowalak, M. Kowalewski, P. Bednarek (red.), Wyzwania w zarządzania kosztami i dokonaniami, Wydawnictwo Uniwersytetu Ekonomicznego, Wrocław.

Szczypa P. (2016), Istota i rodzaje pożądanych zmian w rachunkowości Lasów Państwowych, „Studia Ekonomiczne. Zeszyty naukowe Uniwersytetu Ekonomicznego w Katowicach”, 300.

Szołno-Koguc J. (2007), Funkcjonowanie funduszy celowych w Polsce w świetle zasad racjonalnego gospodarowania środkami publicznymi, Wydawnictwo UMCS, Lublin.

Szramka H., Adamowicz K. (2017), Kierunki modyfikacji statusu Lasów Państwowych w Polsce, ,Sylwan”, 161 (5).

Tyburek M. (2010), Status prawny i zadania Państwowego Gospodarstwa Leśnego Lasy Państwowe [w:] B. Rakoczy (red.), Wybrane problemy prawa leśnego, Wolters Kluwer Polska, Warszawa.

\section{Strony internetowe}

DGLP [Dyrekcja Generalna Lasów Państwowych] (2017), Sprawozdanie finansowo-gospodarcze za 2016 rok, Warszawa, https://bip.lasy.gov.pl/pl/bip/finanse [dostęp: 5.11.2019].

GUS [Główny Urząd Statystyczny] (2017), Leśnictwo 2017, Zakład Wydawnictw Statystycznych, Warszawa, https://stat.gov.pl/obszary-tematyczne/rolnictwo-lesnictwo/lesnictwo/ lesnictwo-2017,1,13.html [dostęp: 5.11.2019].

NIK [Najwyższa Izba Kontroli] (2015), Gospodarka finansowa Lasów Państwowych, https://www.nik.gov.pl/plik/id,9302,vp,11524.pdf [dostęp: 5.11.2019]. 